\title{
Public Defense Innovation in Texas
}

\author{
JAMES D. BETHKE* \\ MORGAN SHELL ${ }^{* *}$
}

"To sound Gideon's trumpet in Texas, we must insist that criminal defendants have qualified counsel who are equipped with the time and resources to mount a meaningful defense."

-Justice Jefferson, Former Chief Justice of the Texas Supreme Court

\section{HISTORICAL CONTEXT}

In 1963, the U.S. Supreme Court held in Gideon v. Wainwright that an indigent criminal defendant charged with a felony has a constitutional right to counsel paid for by the state. ${ }^{2}$ Over time, the Supreme Court expanded this constitutional right to include indigent defendants in juvenile delinquency proceedings and in misdemeanors that result in a defendant's loss of liberty. ${ }^{3}$ But Texas indigents had the benefit of appointed counsel in capital cases well before Gideon, at least seventy-five years before. ${ }^{4}$ Although Texas's foresightedness is commendable, courts only provided counsel when they deemed it "in the interest of justice." Even more, early adoption of the practice led to a "hodgepodge of [criminal] procedures" in Texas's jurisdictions. ${ }^{6}$ Texas was providing indigents with counsel per se, but the lack of state funding and oversight left counties unaccountable. ${ }^{7}$ Gideon did not solve the problem. ${ }^{8}$ The Supreme Court left the implementation and finance of its constitutional guarantee to the states, and Texas delegated the responsibility to its 254 counties. $^{9}$ Counties struggled to bear the

* Chief Defender, Lubbock Private Defender Office (current); Executive Director, Texas Indigent Defense Commission (2002-2017).

** Policy Analyst, Texas Indigent Defense Commission.

1. Hon. Justice Wallace B. Jefferson, The State of the Judiciary in Texas, 76 TEx. B. J. 347, 348 (2013).

2. 372 U.S. 335 (1963).

3. See Argersinger v. Hamlin, 407 U.S. 25 (1972); In re Gault, 387 U.S. 1 (1967).

4. See Tex. Code Crim. Pro. art. 466 (1857), recodified by Tex. Penal Code art. 494 (1925); Powell v. Alabama, 287 U.S. 45 (1932) (discussing differing state applications of right to counsel) And Texas statute required appointment of counsel in all cases capable of actual incarceration seven years before Argersinger. Sharon Keller \& Jim Bethke, Justice for All, 76 TEX. B. J. 189, 189 (2013).

5. James D. Bethke, Rich or Poor: The Right to a Fair Trial Requires a Good Lawyer, 69 TEX. B. J. 238, 239 (2006).

6. Keller \& Bethke, supra note 4, at 189.

7. Id. at 190.

8. See generally id. at 189-90; see also Bethke, supra note 5, at 238-42.

9. Tex. Indigent Def. Comm'n, Fair Defense Law: A Primer for Texas County OfFICIALS 1 (2017), available at http://www.tidc.texas.gov/media/52836/2017_primer-for-countyofficials.pdf [https://perma.cc/M98P-JGWG] [hereinafter PRIMER].

http://doi.org/10.18060/4806.1184 
entire financial burden of the constitutional mandate. ${ }^{10}$ And there was no requirement that appointed attorneys know or practice criminal law. ${ }^{11}$ By 1999 , Texas was one out of nine states in the country not providing state funding or oversight of indigent defense services. ${ }^{12}$ Thousands of Texans were ultimately "pleading guilty or facing trial without benefit of adequate representation."

In 2001, "Texas began a new era in indigent defense." Texas Legislature passed the Texas Fair Defense Act (FDA) addressing this "statewide crisis in the criminal justice system." 15 The Act mandates funding for Texas's 254 counties and oversight of their indigent defense systems, but leaves the specifics of "how to" satisfy the core requirements with each respective local county. ${ }^{16}$ A key component of the Act was the creation of the Task Force on Indigent Defense ("Task Force"), a permanent standing committee of the Texas Judicial Council. ${ }^{17}$ In 2011, the Task Force was renamed the Texas Indigent Defense Commission ("TIDC") pursuant to House Bill 1754 signed by Governor Rick Perry. ${ }^{18}$ Under the leadership of TIDC Chair, the Honorable Sharon Keller, Presiding Judge of the Texas Court of Criminal Appeals, TIDC and its staff of eleven distributes funds to counties, monitors their compliance with state and constitutional requirements, provides counties technical support, and develops Texas indigent defense policies. ${ }^{19}$ In a nutshell, TIDC helps counties develop indigent defense programs that are compliant with the constitutionally mandated standards. ${ }^{20}$ Former Texas State Senator Rodney Ellis, sponsor of the FDA, attributes the Act's success to, among other factors, mandated standards and discretionary grants that incentivize counties to improve indigent defense services. ${ }^{21}$

10. See Tex. Criminal Justice Coal., Texas Indigent Defense Commission: Helping Counties Implement What Works For System-Wide Cost Savings 3 (2013), available at https://www.texascjc.org/system/files/publications/TIDC\%20Helping\%20Counties\%20Feature \%20FOR\%20WEB.pdf [https://perma.cc/22FR-38YX]; Keller \& Bethke, supra note 4, at 189-90. The timing of counsel as well as local funding varied between counties. See Bethke, supra note 5, at 239 .

11. Bethke, supra note 5, at 239.

12. Id.

13. Tex. Criminal Justice CoAL., supra note 10, at 3; Primer, supra note 9, at 1.

14. Keller \& Bethke, supra note 4, at 190.

15. TeX. CRiminal Justice CoAL., supra note 10, at 1.

16. See id.; Bethke, supra note 5, at 239-40.

17. PRIMER, supra note 9, at 1 .

18. Id.; H.R. 1754, 82d Leg., Reg. Sess. (Tex. 2011).

19. Tex. Criminal Justice CoAL., supra note 10, at 1, 5 .

20. Id. at 1 .

21. Id. Rodney Ellis served in the Texas Senate from 1990 to 2017. After he authored and passed the Fair Defense Act in 1999, he actively supported the Texas Indigent Defense Commission in its efforts to bring about innovation by sponsoring legislation including increased funding for indigent defense throughout his tenure in the Texas Senate. Senator Ellis has continued those efforts in Harris County where he was elected County Commissioner and sworn into office on January 1, 
Applying a one-size-fits-all plan to indigent defense is not cost-effective and can impede consistent delivery of indigent defense..$^{22}$ By adopting a "bottom-up approach," TIDC works with local officials to provide them with technical assistance and evidence-based research while ensuring that counties maintain local control. ${ }^{23}$ Texas is making progress in meeting the constitutional demands. ${ }^{24}$ Additional funding and commitment by the Texas Legislature is essential to the continuing success and improvement of indigent defense in Texas. ${ }^{25}$

\section{INNOVATIONS}

TIDC, through its discretionary grant program, ${ }^{26}$ technical assistance, and longtime collaboration with Texas A\&M Public Policy Research Institute ("PPRI"), has forged meaningful advancements in the administration of quality, cost-effective indigent defense delivery systems across the State of Texas. ${ }^{27}$

\section{A. Regional Public Defender Office for Capital Cases}

In the most serious criminal cases where defendants face the penalty of death, the State has a unique interest in ensuring that defense representation is consistent with constitutional standards as well as the professional standards promulgated by the State Bar of Texas. ${ }^{28}$ Death penalty cases are complex and timeconsuming. Finding attorneys with the adequate skill and resources to manage such cases is especially challenging in parts of rural Texas. ${ }^{29}$

Texas spans 268,000 square miles and has a population of around 27.4 million people. ${ }^{30}$ But only a minority brave the vast desert dry land that is rural

2017. See Jonathan Silver, Rodney Ellis leaves Texas Senate with criminal justice legacy, TEX. TRIB. (Jan. 8, 2017, 12:00 AM), https://www.texastribune.org/2017/01/08/rodney-ellis-leavestexas-senate-criminal-justice-/ [https://perma.cc/2U89-RCE4].

22. See generally Tex. CRiminal Justice CoAL., supra note 10, at 6.

23. Id.

24. Bethke, supra note 5, at 242.

25. TeX. Criminal Justice CoAl., supra note 10, at 1.

26. TIDC awards discretionary grants to assist counties in developing new and innovative programs and to help them remedy noncompliance with the FDA. TEX. INDIGENT DEF. CoMm'N, ANNUAL AND EXPENDITURE REPORT 4 (2015), available at http://www.tidc.texas. gov/media/41870/2015-annual-and-expenditure-report_final.pdf [https://perma.cc/43TW-RSJ2] [hereinafter ANNUAL REPORT 2015]. TIDC offers counties applications to four discretionary grants including competitive discretionary grants, technical support grants, targeted specific grants, and extraordinary disbursement grants. Id. In 2015, TIDC awarded \$6.9 million in new and continuing discretionary grants to eighteen counties. Id.

27. Id. at 21 .

28. Tex. Indigent Def. Comm'n, Legislative Appropriations Request for Fiscal YEARS 2018 AND 20195 (2016), available at http:/www.tidc.texas.gov/media/48308/final-lar-fy1819_revised-9-12.pdf [https://perma.cc/4J3R-LXQ8] [hereinafter LAR REPORT 18/19].

29. Id

30. NAT'L Ass'N For Pub. Def., RPDO:MAKIng A DifFERENCE In TEXAs 6 (2016), available 
West Texas. ${ }^{31}$ The majority of its population live in cities. ${ }^{32}$ Consequently, most resources are concentrated around these dense urban areas. ${ }^{33}$ West Texans lacked qualified lawyers willing to accept capital appointments. ${ }^{34}$ Yet the region was not untouched by crime. ${ }^{35}$ Over a ten-year survey, Lubbock and its eighty-four neighboring counties in West Texas ${ }^{36}$ were averaging approximately twenty-five capital murders per year. ${ }^{37}$

To address this challenge, Lubbock County applied for a discretionary grant in 2008 through the Task Force on Indigent Defense. ${ }^{38}$ In its application, Lubbock noted that "[p]roviding quality indigent defense for capital murder defendants in the 7th and 9th Administrative Judicial Regions ha[d] become increasingly difficult to accomplish[,]" because there was an inadequate number of qualified counsel available for appointment. ${ }^{39}$ The attorneys who were accepting these cases were hurting their private practice in doing so. ${ }^{40}$ Lubbock explained that the cost of death penalty cases ranged anywhere from $\$ 100,000$ to $\$ 250,000{ }^{41}$ " As such, many counties [were] essentially unable to provide the defense services without [bankrupting] the county or sacrificing quality." 42 It listed seven objectives it wished to accomplish through a discretionary grant program: (1) provide expert qualified counsel from a Public Defender office for all defendants charged with capital murder, except those cases in which a conflict exists; (2) provide attorney contact within twenty-four hours of appointment for defendants accused of capital murder; (3) provide litigation support services for all capital murder cases assigned to the public defender through the use of mitigation specialists and investigators services; (4) maintain a manageable caseload of open capital murder cases, not to exceed five active cases per attorney at any one time; (5) demonstrate quality representation as determined by judges and appellate counsel assigned to capital murder cases; (6) reduce the litigation cost per case

at http://www.tidc.texas.gov/media/52840/napd-reporton-rpdo-jan 2017 -.pdf [https://perma.cc/F8QS-6Z9T] [hereinafter NAPD].

31. See id.

32. Id.

33. Id.

34. Id.

35. See generally Reg'l Pub. Def. for Capital Cases, RPdo History and Regional OverviEw (2013) (on file with Texas Indigent Defense Commission).

36. In 2007, Lubbock County, with a population of around 266,719, was the largest county in the region. Texas Population, 2007, Tex. Health \& Human Servs., https://www.dshs.texas. gov/chs/popdat/ST2007.shtm [https://perma.cc/C89K-X78Q] (last updated Jan. 31, 2014).

37. Reg'l Pub. Def. For CAPITAL CASES, supra note 35.

38. NAPD, supra note 30 , at 7.

39. Tex. Indigent Def. Comm'n, 2008 Lubbock County Discretionary Grant ApPlication NARRATIVE 5 (2008), available at https:/tidc.tamu.edu/DGSGA/281.pdf [https://perma.cc/XEN5-Q6N4 ] (on file with Texas Indigent Defense Commission).

40. Id.

41. Id. at 5-6.

42. Id. at 6 . 
for capital murder cases in the seventh and ninth Administrative Judicial Region; and (7) use the grant funded period to establish a reasonable funding model that the Task Force and Texas counties can use to fund other regions' indigent defense processes. ${ }^{43}$

The Task Force approved a grant request and the regional public defender office for capital cases ("RPDO") was operational in January $2008 .^{44}$ It was designed to make high-quality capital defense representation more accessible in small and mid-sized jurisdictions as well as enhance budget predictability ${ }^{45}$ The costs of a capital case can overwhelm a county budget. ${ }^{46}$ Representation is complex and, at least in rural regions, finding attorneys with the requisite skill and support resources to carry a death penalty case is challenging. ${ }^{47}$ The RPDO program bridged this gap. ${ }^{48}$ It is structured like an insurance policy-in exchange for payment of annual membership dues, counties are provided a defense team at no extra charge when a death penalty case arises. ${ }^{49}$ This helps counties avoid having to pay large sums of money for counsel in capital cases. ${ }^{50}$

The RPDO is available to counties with populations under $300,000 .{ }^{51}$ It is operated by Lubbock County and, thanks to its success, has seen rapid expansion by way of requests from other counties electing to "opt-in on a biennial basis." 52 The RPDO now serves 179 counties and houses satellite capital litigation offices in Lubbock, San Antonio, Burnet, Amarillo, Clute, Wichita Falls, Terrell, and Midland. ${ }^{53}$

Because of its expansion and commitment from the Lubbock County Commissioner's Court "as well as leadership at the state level that . . . have sustained it in its development[,]" the program has "resolve[d] a remarkable

43. See NAPD, supra note 30 , at 7.

44. Id. The program was expanded through subsequent grants to cover counties in all regions of the state. Id. TIDC disbursed \$17,309,038 from 2008-2016. TIDC Discretionary Grant Payments, TeX. Indigent DeF. COMm'N, https://tidc.tamu.edu/DiscretionaryGrantProgram/ DGPayments.asp [https://perma.cc/4FEC-J458] (last visited Sept. 28, 2017).

45. Dottie Carmichael \& Heather Caspers, Tex. A\&M Pub. Policy Research Inst., Judgment and Justice: An Evaluation of the Texas Regional Public Defender for Capital Cases vii (2013) [hereinafter Judgment and Justice].

46. See generally Maria Sprow, Insurance: Regional Capital Public Defender's Office implements innovative approaches to give counties budget predictability, COUNTY MAG., Sept.-Oct. 2008, at 19, 21, available at $\mathrm{http} / / /$ tidc.texas.gov/media/36963/080910_LubbockMurderInsurance CountyMag.pdf [https://perma.cc/JHG9-L934].

47. Id. at 20 ; NAPD, supra note 30 , at 7 .

48. See Sprow, supra note 46, at 20.

49. See id. at 19-20.

50. Id.

51. See NAPD, supra note 30 , at 7 .

52. Id. at 17.

53. LAR REPORT 18/19, supra note 28, at 4; Texas Regional Public Defender's Office, About Us, REG'L PUB. DEF. FOR CAPITAL CASES, http://rpdo.org/about.php [https://perma.cc/UE5E-5JTA] (last visited Sept. 28, 2017). 
number of cases to a sentence other than death." ${ }^{54}$ Since its inception, the RPDO has closed 112 cases. ${ }^{55}$ One RPDO attorney has settled thirty-three cases, avoiding trial in all but one case. ${ }^{56}$ The ABA conducted an assessment of the death penalty in Texas and reported that the RPDO was a "significant step forward in the improvement of the quality of representation available to Texas's indigent defendants and inmates in death penalty cases." ${ }^{57}$ Another report by PPRI noted that "it was more independent from judicial influence than private counsel in capital cases" and it resulted in "lower cost-per-case than using private counsel." 58 Overall, PPRI concluded that the "RPDO increases access, improves quality, and reduces costs of death penalty representation in small to mid-sized counties." ${ }^{59}$

The program is now effectively operating as a capital law firm. ${ }^{60}$ Its success can be accredited to a number of laudable goals: (1) a commitment to clients; (2) a commitment to mitigation; (3) teamwork throughout the organization; (4) reasonable salaries for participating attorneys; (5) caps on cases per attorney; and (6) a community of committed persons. ${ }^{61}$ The defender program is now the "largest collaborative effort between [c]ounties and a state-funded program" in the country. ${ }^{62}$

The office also gives students at the Texas Tech University School of Law an invaluable opportunity to assist in the representation of defendants charged with capital murder. ${ }^{63}$ Four students from the Capital Punishment Clinic are invited to work with the RPDO during the Spring semester. ${ }^{64}$ Students get to apply their legal education to a wide variety of activities including investigation, legal research and writing, motion drafting, and client interviewing, and will receive exposure to criminal procedure and criminal law in an actual legal setting. ${ }^{65}$ Students are closely supervised by Professor Patrick S. Metze, Director of the Criminal Defense Clinics, and Adjunct Professor Ray Keith, Chief Public

54. NAPD, supra note 30 , at 17.

55. Id.

56. Id.

57. Id. at 8 (quoting Am. Bar Ass'n, Evaluating Fairness and Accuracy in State Death Penalty Systems: The Texas Capital Punishment Assessment Report iv (2013), available at https://www.americanbar.org/content/dam/aba/administrative/death_penalty_ moratorium/tx_complete_report.authcheckdam.pdf [https://perma.cc/E5VW-JHWF]).

58. Id.

59. Id. (quoting JUDGMENT AND JustiCE, supra note 45, at ix).

60. Id. at 17 .

61. Id. at 17-19.

62. Texas Regional Public Defender's Office, supra note 53.

63. Capital Punishment Clinic, TEX. TECH SCH. OF LAw, http://www.depts. ttu.edu/law/clinics-and-externships/clinics/cap-punishment/ [https:/perma.cc/N9ER-GCYK] (last visited Apr. 13, 2017).

64. Id.

65. Id. 
Defender for Capital Cases. ${ }^{66}$

\section{B. Caprock Regional Public Defender Office}

After implementation of the RPDO, TIDC discovered unusually low misdemeanor appointment rates in the rural Caprock region of Texas. ${ }^{67}$ Counties lacked basic elements of indigent defense - sporadic caseloads, criminal defense attorney shortages, and insufficient resources permeated the region's indigent defense structures. ${ }^{68}$ Appointment rates for misdemeanors ranged from zero to twenty-two percent. ${ }^{69}$ TIDC and other stakeholders explored the possibility of adapting the RPDO concept to address these deficiencies. ${ }^{70}$ After meeting and coordinating with Panhandle counties interested in forming a regional public defense program, the Caprock Regional Public Defender Office (“CRPDO”) was born through TIDC's discretionary grant program..$^{71}$ At the request of Dickens County, Texas Tech University School of Law agreed to take a leading role as public defender, making it one of "the only combined full-time, in-house public defender's office and law school clinic[s] in the country." $" 72$ Ten counties initially participated in the program; six other counties have since then joined. ${ }^{73}$ The CRPDO is qualified to represent indigent defendants in misdemeanor, juvenile, and felony cases. ${ }^{74}$ Since inception, the program has expanded to include appeals. ${ }^{75}$ Notably, in its first appellate case in 2012, a state appellate court acquitted CRPDO's client on a charge of attempted theft and overturned a conviction on a charge of burglary of a vehicle. ${ }^{76}$ TIDC also allocates a portion of the program's grant money to develop technology assistance. ${ }^{77}$ Thanks to a

66. Id.

67. Tex. Criminal Justice Coal., supra note 10, at 9.

68. See Tex. Indigent Def. Comm'n, Annual and Expenditure Report 9 (2012), http://www.tidc.texas.gov/media/18587/fy12annualreport.pdf [https://perma.cc/5ZNX-6MNE] [hereinafter ANNUAL REPORT 2012].

69. Public Hearing Before the Texas Senate Committee on Intergovernmental Relations, 2014 Leg., 83d Sess. 6 (Tex. 2014) (written testimony of Jim Bethke, former Executive Director of the Texas Indigent Defense Commission), available at http:/www.senate.state.tx.us/ cmtes/83/c520/IGR_20141023_TIDC_JimBethke.pdf [https://perma.cc/VPR5-E4E6].

70. TeX. CRiminal Justice CoAL., supra note 10, at 9.

71. Id. Beginning in 2016, the grant has been awarded directly to Texas Tech University School of Law following a change in the state statute detailing grant eligibility. TIDC has disbursed \$1,881,941 for this program from 2011-2016. TIDC Discretionary Grant Payments, supra note 44.

72. Kari Abitbol, School of Law Enacts Public Service Graduation Requirement, TEX. TECH UNIV. (Sept. 1, 2015), http://today.ttu.edu/posts/2015/09/school-of-law-enacts-public-servicegraduation-requirement [https://perma.cc/T9L2-JVAM].

73. TeX. Criminal Justice CoAL., supra note 10, at 9.

74. Id.

75. AnNUAL RePORT 2012, supra note 68, at 10.

76. Id.

77. See id. at 9. 
"sophisticated videoconference system," the CRPDO ensures defendants timely access to counsel and enables CRPDO attorneys to maintain regular contact with their clients. ${ }^{78}$

While highly skilled criminal defense lawyers oversee representation of CRPDO's clients, Texas Tech's third-year law students are largely responsible for the cases from intake through disposition. ${ }^{79}$ Donnie Yandell, Chief Public Defender, CRPDO, summarizes it well, "[t]his is not your typical law school clinic[.]" ${ }^{\prime 0}$ He expounds that the "students are not just observing attorneys in action; they are actually handling cases from start to finish .... And more often than not, they secure dismissals for their clients." ${ }^{\prime 1}$ Running the CRPDO through the law school has many benefits; the office has access to the University's resources and, in turn, the program gives law students invaluable courtroom experience, which allows them to develop valuable skills and foster a commitment to indigent defense. ${ }^{82}$ The participation of Texas Tech Law Criminal Defense Clinic was critical to counties in West Texas that joined the program. ${ }^{83}$ The Defense Clinical Director at Texas Tech explained that the dearth of private attorneys available in the region had resulted in an "underserved population." 84 Through the participation of Texas Tech University School of Law, CRPDO has greatly impacted the volume of indigent defendants receiving criminal defense representation in participating counties ${ }^{85}$ Its demonstrable success provides Texas with a workable model that can and should be replicated in other regions experiencing similar challenges.

\section{South Texas Regional Defender Contract with Texas RioGrande Legal Aid}

Texas RioGrande Legal Aid (TRLA) was originally dedicated to providing free civil legal services to indigent residents throughout Central, South, and West Texas. ${ }^{86}$ Indigents facing criminal charges still had limited access to qualified

78. $I d$.

79. Id.; Caprock Regional Public Defender Office, TeX. ТЕCH SCH. OF LAW, https://www.depts.ttu.edu/law/clinics-and-externships/clinics/crpd/ [https://perma.cc/9MJD-6V6V] (last visited Apr. 24, 2017).

80. Tex. Indigent Def. Comm'n, Annual and Expenditure Report 11 (2014), http://www.tidc.texas.gov/media/30757/fy14annual-report141229.pdf [https://perma.cc/8FE59H7X] [hereinafter ANNUAL REPORT 2014].

81. Id.

82. Tex. Criminal Justice CoAL., supra note 10, at 10.

83. Id. at 9-10.

84. Tina Dechausay, Caprock Regional Public Defender Office Nearing Reality, TEX. TECH SCH. OF LAW (Nov. 10, 2010), http://today.ttu.edu/posts/2010/11/caprock-regional-public-defenderoffice-nearing-reality [https://perma.cc/ZQ3V-T82A].

85. Id.

86. See Our History, TeX. RioGrande LeGAL AID, InC., http://www.trla.org/about/ourhistory [https://perma.cc/8EVP-B3YB] (last visited Oct. 8, 2017). 
defense counsel. ${ }^{87}$ Southwest Texas has historically housed some of the poorest counties in the nation. ${ }^{88}$ Employment rates are low and the wages drive thousands into migrant labor. ${ }^{89}$ Consequently, these rural regions struggle to maintain compliance with Sixth Amendment and FDA mandates. ${ }^{90}$ With the financial help of TIDC, TRLA expanded its civil program in 2009 to include a regional public defender program, headquartered in the lower Rio Grande Valley, that would assist these largely underserved counties. ${ }^{91}$ The program is the leading provider of legal aid in Texas and now has branches throughout the state, providing a full range of high quality legal representation from initial screenings and trials to misdemeanors, felonies, appeals, and juvenile cases. ${ }^{92}$

In 2009, TRLA opened the Bee County Public Defender (“BCPD”) office as part of a five-year discretionary grant award by TIDC. ${ }^{93}$ The office provides free legal services to low-income residents of Bee, Live Oak, and McMullen counties. ${ }^{94}$ TRLA estimates that the program will help over 1,500 low-income residents with criminal matters each year. ${ }^{95}$ The program is dedicated to helping the counties comply with appointment timeframes-BCPD staff screeners visit the jails daily to identify arrestees that might qualify for the program. ${ }^{96}$ Its commitment to early screening has resulted in appointments usually soon after arrest. $^{97}$

BCPD's contract with TRLA gives it access to various services relating to the consequences of a client's criminal case. ${ }^{98}$ The defender program provides its clients with referrals to social services and veterans' benefits and helps them obtain occupational licenses. ${ }^{99}$ TRLA is also well-versed in immigration and mental illness issues. ${ }^{100}$ It staffs an immigration lawyer as well as an attorney who specializes in mental health issues - to which all of TRLA's branches have

87. Telephone Interview with David Hall, Executive Director, TRLA (Mar. 20, 2017).

88. See Trymaine Lee, Dark Valley: Life in the Shadows, MSNBC, http://www.msnbc.com/ interactives/geography-of-poverty/sw.html [https://perma.cc/63US-EXMY] (last visited Dec. 5, 2017).

89. Id.

90. See ANNUAL RePORT 2012, supra note 68, at 1.

91. Tex. Lawyers Care, Public Defender Program Opens to Help the Poor, 10 LEgALFront, no. 3, Summer 2009, at 24.

92. See Who We Are, Tex. RioGrande LegAL Aid, InC., http://www.trla.org/about/who-weare [https://perma.cc/RN9R-YV55] (last visited Oct. 8, 2017).

93. Tex. Indigent Def. Comm'n, Bee County Regional Public Defender (on file with Texas Indigent Defense Commission).

94. Tex. Lawyers Care, supra note 91, at 24.

95. Id.

96. See AnNuAl Report 2015, supra note 26, at 8.

97. Id.

98. Id.

99. Id.

100. Id.; Telephone Interview with David Hall, supra note 87. 
access. ${ }^{101}$ BCPD is currently considering adding a social worker to its staff. ${ }^{102}$ Not surprisingly, the office has earned a reputation for its quality of legal services. ${ }^{103}$ By 2015, the appointment rate in Bee County had increased by $26.9 \%$ and BCPD had closed 683 cases. ${ }^{104}$ Most recently, BCPD received the 2017 Texas Gideon Recognition Program award for its commitment to meeting a high standard of indigent defense. ${ }^{105}$ The turnkey program also "enjoys strong support from judges and county commissioners" who do not have to invest in training, supervision, and management of court appointed attorneys. ${ }^{106}$ Most importantly, it ensures low-income Texans enjoy equal access to justice - a concept everyone can get behind.

\section{PRIVATE DEFENDER AND MANAGED Assigned CoUnSEl PROGRAMS}

Around 2010, the Task Force proposed legislation that would clearly define managed assigned counsel ("MAC") programs and authorize local jurisdictions to establish them as an alternative to ad hoc assigned counsel programs. ${ }^{107}$ At the time, Texas's statute was silent on the operation or establishment of MAC programs. ${ }^{108}$ Article 26.04 (Procedures for Appointing Counsel) of the Code of Criminal Procedure permitted a county to establish an indigent defense system based on the default rotation model, which included a public defender office, or that fit into the definition of an "alternative program." 109 But a MAC program did not fall under either category. ${ }^{110}$ The statute required judges to screen defense attorneys seeking to receive appointments. ${ }^{111}$ Under the MAC system, screening is the job of nonprofit or government offices, not judges. ${ }^{112}$ Similarly, because

101. Telephone Interview with David Hall, supra note 87.

102. Id.

103. See ANNUAL RePORT 2015, supra note 26, at 8.

104. Id.

105. Gideon Recognition Program, Tex. Indigent Def. Comm'N, http:/tidc.texas.gov/ resources/publications/general/awards-recognition/texas-gideon-recognition.aspx [https://perma.cc/J6W5-PD57] (last visited Dec. 5, 2017).

106. See Annual Report 2015, supra note 26, at 8.

107. See Tex. Indigent Def. Comm'n, Annual and Expenditure Report 4-5 (2011), available at $\mathrm{http}: / /$ tidc.texas.gov/media/18586/fy1 1 annualreport.pdf [https://perma.cc/P2VU-J43U]. Under an ad hoc system, private attorneys are appointed from an appointment list by a judge. The Four Types of Defense Delivery Systems, Tex. Indigent Def. Comm'N (Jan. 2015), tidc.texas.gov/media/30127/Defense_DeliverySystem_January2015.ppt [https://perma.cc/URJ7BBE2] [hereinafter Four Types of Defense].

108. See Duncan, S. ReSearch Ctr., S.B. 1710 Bill Analysis, S. 81st Leg., Reg. Sess. (Tex. 2009), at 1, available at $\mathrm{http} / / / w w w . l r l . s t a t e . t x . u s / s c a n n e d /$ srcBillAnalyses/81-0/SB1710RPT.PDF [https://perma.cc/VPY8-DHWC] [hereinafter S. RESEARCH CTR.].

109. Id at 1-2.

110. See id. at $1-3$.

111. Id. at 1 .

112. See id. at 2-3. 
the proposed program does not itself provide legal representation, it could not fall under the umbrella of a "public defender" for purposes of the statute. ${ }^{113}$

In 2011, the eighty-second Texas State Legislature authorized the establishment of managed assigned counsel programs. ${ }^{114}$ By definition, the programs "operate with public funds; by a governmental entity, nonprofit corporation, or bar association under a written agreement with a governmental entity, other than an individual judge or court; and for the purpose of appointing counsel under Article 26.04 of [the Texas Code of Criminal Procedure] or Section 51.10 of the Family Code." 115 The entity is responsible for screening attorneys for court-appointment eligibility, assigning lawyers to cases, and approving requests for investigative and expert assistance. ${ }^{116}$

MAC programs give jurisdictions the ability to deliver indigent defense services with direct oversight. ${ }^{117}$ They also relieve judges and court personnel from most of the administrative burdens that accompany managing indigent defense. ${ }^{118}$ Notably, this type of structure comes closer to meeting national standards for public defense services than the judicially-managed assigned counsel system most common in Texas. ${ }^{119}$

Although relatively new to Texas, similar programs have been developed in Colorado, San Mateo, California, and Pima County, Arizona for some time. ${ }^{120}$ A trip to San Mateo County, California in 2008 with Dean Norm Lefstein, who was writing his book, Securing Reasonable Caseloads, provided the inspiration to apply this model in Texas. San Mateo County established the program in the late sixties, and it has proved to be an exemplary model for providing indigent defense services. ${ }^{121}$

Nevertheless, jurisdictions are free to employ an attorney appointment system that fits their specific needs. The FDA is largely effective because it does not force a one-size-fits-all model on counties. For instance, larger counties may benefit from a public defender ("PD") system, which provides for defense services and representation by a county or state agency. ${ }^{122}$ PD programs facilitate budget predictability and provide systematic attorney training and supervision. ${ }^{123}$ However, a PD system has substantial start-up costs and is often more difficult

113. Id. at 1 .

114. See H.R. 1754, 82d Leg., Reg. Sess. (Tex. 2011).

115. See Tex. Code Crim. Proc. AnN. art. 26.047 (West 2011) (emphasis added).

116. See Four Types of Defense, supra note 107.

117. Id.

118. Id.

119. See Am. Bar Ass'n, Ten Principles of a Public Defense Delivery System 1-3 (2002).

120. See S. ReSEARCH CTR., supra note 108, at 1.

121. Private Defender Program, CTY. OF SAN MATEO, http://www.smcgov.org/privatedefender-program [https://perma.cc/6GXR-42Z3] (last visited Oct. 8, 2017).

122. See Four Types of Defense, supra note 107.

123. Id. 
to justify in a smaller county. ${ }^{124}$ It can also facilitate caseload problems and is susceptible to politicization. ${ }^{125}$

MAC programs, in contrast, shift administration of the defense function from courts to a defense entity that has the resources and skills to provide the county with indigent defense services. ${ }^{126}$ The system allows counties to achieve some of the benefits of a public defender system within an assigned counsel framework. ${ }^{127}$ MAC programs reduce time burdens and administrative costs, and they do not require a secondary system for conflict cases like PD offices. ${ }^{128} \mathrm{MAC}$ programs are acclaimed for improving oversight and accountability of indigent defense services through systematic attorney training and monitoring of attorney performance and caseloads. ${ }^{129}$ Moreover, using the private sector to provide direct client services enables counties to enhance the independence of their system's defense function. ${ }^{130}$

Two counties stand out-Travis and Lubbock have transitioned from the traditional ad hoc assigned counsel program to a fully managed assigned counsel operation. ${ }^{131}$ Initially, Lubbock County, through a discretionary grant, established a pilot managed assigned counsel program to only represent mentally ill offenders. ${ }^{132}$ Capitalizing on its success, the county expanded the program to handle all indigent criminal cases. ${ }^{133}$ In 2015, TIDC granted Travis County a discretionary grant in the amount of $\$ 717,516$ to create and operate a MAC

124. $I d$.

125. Id.

126. Id.

127. Id.

128. Id. As required by Article 26.047 of Texas's Code of Criminal Procedure, MACs have a program director with extensive experience in the practice of criminal law. See TEX. CodE CRIM. PROC. ANN. art. 26.047 (West 2011). Although not required, counties find it beneficial to establish an oversight committee as well, composed of key stakeholders, to help supervise a program. Id. If the program appoints a review committee of three or more individuals who meet the requirements of Article 26.047 of the Texas Code of Criminal Procedure, a county is not required to appoint a program director. Id.

129. Four Types of Defense, supra note 107.

130. Id.

131. Tex. Indigent Def. Comm'n, Fiscal Monitoring Report: Travis County, Texas 4 (2016), available at http://www.tidc.texas.gov/media/49963/travis-county-final-report.pdf [https://perma.cc/T3B8-UX7G] [hereinafter TRAVIS CTY. ReporT]; Indigent Defense Plans: Lubbock County, Tex. Indigent Def. Comm'N (Oct. 24, 2017), http://tidc.tamu.edu/public.net/ Reports/IDPlanNarrative.aspx?cid=152 [https://perma.cc/4X34-XU2N].

132. See Partnerships Help Mentally Ill Defendants Get Treatment, Services \& Stay Away From Jail, CounTy MAG., Sept.-Oct. 2011, at 30, available at http:/tidc.texas.gov/media/ 36610/111009_tacbestpractices_lubbocksndo.pdf [https://perma.cc/E7UD-H68B] [hereinafter Partnerships].

133. Tex. Indigent Def. Comm'n, Indigent Defense Programs in Lubbock, Texas (on file with Texas Indigent Defense Commission) [hereinafter Indigent Defense Programs Lubbock]. 
program. ${ }^{134}$ Discretionary grants enable counties to, among other things, test innovative ways to deliver better indigent defense services. ${ }^{135}$ They also incentivize counties to implement plans compliant with the FDA. ${ }^{136}$ The results are encouraging.

\section{A. Travis County: The Capital Area Private Defender Service ("CAPDS")}

CAPDS is the non-profit organization responsible for implementing the MAC program in Travis County, which is now the largest MAC program in Texas. ${ }^{137}$ A unique feature of the program is the CAPDS Review Committee, which selects and oversees approximately 200 criminal defense attorneys. ${ }^{138}$ The committee is composed of practiced criminal lawyers with at least ten years of experience. ${ }^{139}$ The CAPDS Board of Directors oversee the hiring of the Executive Director and provide guidance in developing policies and procedures in furtherance of indigent defense. ${ }^{140}$

Before CAPDS, judges made around forty-three percent of appointments from the bench in Travis County. ${ }^{141}$ Bench appointments are now under three percent, and defendants who have issues with their attorneys "no longer have to risk disclosing confidential information to a judge" to resolve the issue. ${ }^{142}$

Under the MAC program, qualified criminal defense attorneys are appointed to indigent defendants via an appointment wheel (occasionally CAPDS will have good cause to assign an attorney out of rotation order). ${ }^{143}$ The program also manages and trains six contract investigators who help defense attorneys take statements from witnesses and investigate the clients' prospective defenses. ${ }^{144}$

CAPDS has revolutionized the technological resources available to attorneys. By filling out a short form on its website, for instance, a CAPDS attorney can have access to an expert or investigator - quite literally at the click of a mouse. ${ }^{145}$ TIDC funding also contributed to the development of the CAPDS website, which is "unparalleled in its abilities." 146 The technology immediately alerts CAPDS attorneys of significant events including their client's release from jail or the

134. TRAVIS CTY. RePORT, supra note 131 , at 4.

135. See generally ANNUAL REPORT 2015, supra note 26.

136. Id. at 4 .

137. Capital Area Private Def. Serv., Annual Report 8, 12 (2016) [hereinafter CAPDS REPORT 2016].

138. Id. at 11; TrAvis CTY. RePORT, supra note 131, at 5.

139. CAPDS REPORT 2016, supra note 137, at 11.

140. Id. at 10 .

141. Capital Area Private Def. Serv., Annual Report 10 (2015) [hereinafter CAPDS REPORT 2015].

142. Id.

143. TRAVIS CTY. RePORT, supra note 131, at 5.

144. Id. at 18 .

145. Id. at 11 .

146. CAPDS REPORT 2016, supra note 137, at 16. 
issuance of a warrant or indictment. ${ }^{147}$ Likewise, investigators receive their assignments and submit payment vouchers through the portal. ${ }^{148}$

CAPDS came into existence through innovation and continues to use that medium to improve the criminal justice system. ${ }^{149}$ Technology, for CAPDS, is the "very fabric" of its existence. ${ }^{150}$ Many of its innovations deserve mention. In its "Attorneys of the Day Program," CAPDS lawyers sign up on an appointment "on call" list on the CAPDS website. ${ }^{151}$ Through real-time text messaging via its computer-based texting tool, CAPDS can dispatch an attorney within fifteen minutes of a court's request, preventing defendants from appearing in court without representation. ${ }^{152}$ Last year, the Attorneys of the Day component of the program dispatched 1,888 attorneys ultimately enhancing fair distribution of assignments and improving indigent defense in Travis County. ${ }^{153}$

CAPDS has become a key defense resource for other criminal justice agencies because of its quality defense work and reputation for competent and diligent attorneys. In 2015, the Texas Forensic Science Commission ("TFSC") reviewed thousands of convictions involving incorrect statistical interpretations of DNA mixtures in an Austin forensic lab. ${ }^{154}$ During review, it discovered that problems with the calculation of DNA could have materially affected the outcome of thousands of cases. ${ }^{155}$ TFSC called upon a number of stakeholders including CAPDS to develop a review plan. ${ }^{156}$ CAPDS agreed to perform defense materiality reviews of up to 4,000 cases. ${ }^{157}$ Using TIDC funding, it hired two parttime defense attorneys to carry out the project and is currently reviewing convictions stemming from the systemic problems at the Austin lab. ${ }^{158}$ TIDC also assisted in the case review initiative by providing funding for a coordinated team

147. Id. at 17 .

148. Id. at 16 .

149. Id. at $8,16-18$.

150. Id. at 8 .

151. TRAVIS Cty. RePORT, supra note 131 , at 5.

152. CAPDS REPORT 2016, supra note 137, at 18.

153. Id.

154. Sandra Guerra Thompson \& Nicole Bremner Casarez, Building Infrastructure For “Justice Through Science”: The Texas Model, 119 W. VA. L. REV. 711, 744-45 (2016).

155. Id.

156. Id.

157. CAPDS REPORT 2016, supra note 137, at 30; see also Elizabeth Findell, After lab closure, daunting questions on DNA-based convictions remain, AM. STATESMAN (Nov. 27, 2016, 5:07 PM), http://www.mystatesman.com/news/local-govt--politics/after-lab-closure-dauntingquestions-dna-based-convictions-remain/vXMNsnGORQOx9N8kkNpTtN/ [https://perma.cc/53RM-VFP7] (number of cases estimated pending review).

158. CAPDS REPORT 2016, supra note 137, at 30. In addition to Harris County, TIDC awarded grants to Travis County and Tarrant County for a DNA Mixture Post-Conviction Review Project. TIDC Discretionary Grant Payments, supra note 44. In total, TIDC disbursed $\$ 187,749$ to Harris County in 2016 for the project. Id. In regards to Travis County, TIDC disbursed \$503,945 to the MAC program in the 2016 fiscal year. Id. 
of experts to help notify indigent defendants whose cases were affected by the new protocols for DNA mixtures and provide legal representation where needed. ${ }^{159}$ Texas ultimately became the first and, as of early 2016 , the only state to systematically and proactively address this systemic issue. ${ }^{160}$

CAPDS devotes significant resources to training its staff. ${ }^{161}$ All attorneys admitted to the CAPDS rotation wheel complete a rigorous screening and training process and must meet a minimum number of trial requirements. ${ }^{162}$ CAPDS's trial training programs emphasize client-centered representation and focus on teaching attorneys how to "inform juries of their defense in a persuasive manner."

In an effort to aid and promote the use of multi-disciplinary teams to represent all of the client's needs, TIDC granted CAPDS's proposal to enhance its program in 2016, which provides funding for one full-time immigration attorney and two social workers. ${ }^{164}$ The MAC program is now one of the few assigned counsel programs in the country to incorporate immigration attorneys and social workers into its system. ${ }^{165}$ The use of multi-disciplinary teams addresses a client's needs more effectively with an end goal of keeping the client out of the criminal justice system. ${ }^{166}$ Often, an arrest will trigger problems with immigration, employment, and housing. ${ }^{167}$ Helping defendants with these problems in addition to the criminal charge can facilitate a more effective transition back into society. ${ }^{168}$

By establishing meaningful standards of quality representation, monitoring the work of assigned counsel, providing training and educational services, and developing innovative technological advancements in its criminal defense system, CAPDS is innovating the delivery of indigent defense in Texas and improving the lives of its indigent clients. ${ }^{169}$

\section{B. Lubbock County: Managed Assigned Counsel (MAC) Program}

Lubbock was already making innovative changes in the area of mental health when TIDC first proposed a private defender's office designed to serve indigent defendants with mental illness. ${ }^{170}$ One judge from the 237th District Court, reflecting on a moment of clarification, explains that the issue first received

159. Thompson \& Casarez, supra note 154 , at $745-46$.

160. Id.

161. See CAPDS REPORT 2016, supra note 137, at 20.

162. CAPDS REPORT 2015, supra note 141, at 11.

163. Id. at 22 .

164. CAPDS REPORT 2016, supra note 137, at 28.

165. Id. at 32 .

166. Id. at 26 .

167. Id.

168. Id.

169. See id. at 4,8 .

170. See generally Mary Alice Robbins, First and Goal: LCDLA Close to Creating Nonprofit to Run Private Defender's Office, TEx. Law., Aug. 11, 2008. 
exposure after a mentally ill defendant became "irate" when a vending machine at the Lubbock Police Department took his money without dispensing a candy bar. ${ }^{171}$ The man continued to pound on the machine after a police officer told him to stop and "the incident escalated to the point where the man was charged with assault on a police officer." ${ }^{172}$ After working with law enforcement, the judge resolved the case without sending the man to prison. ${ }^{173}$ The judge explained that if the court could resolve the issue with that individual, it could "do it on a million [individuals with mental illness]." ${ }^{\prime 174}$ Around that time, Lubbock County was already working with the Lubbock Regional Mental Health and Mental Retardation Center to offer services to inmates struggling with mental health issues. ${ }^{175}$

Despite these efforts, mentally ill defendants were still spending a "disproportionate amount of time" in jail. ${ }^{176}$ Lubbock officials took notice. ${ }^{177}$ After careful study, they concluded that mentally ill inmates could not escape the system without outside help. ${ }^{178}$ Lubbock county was ill equipped to handle cases dealing with mentally ill defendants. ${ }^{179}$ Although it had a mental health wheel, the county lacked the resources to provide adequate counsel, and the training that it did offer was voluntary. ${ }^{180}$ Lubbock ultimately applied for a discretionary grant from TIDC, and the Lubbock County Special Needs Defenders' Office, Texas's first managed assigned counsel program for the mentally ill, was created soon after. ${ }^{181}$ Officially, the office was established by the Lubbock Criminal Defense Lawyers Association ("LCDLA"). ${ }^{182}$ The county then hired the office to administer the managed assigned counsel program. ${ }^{183}$ It had the advantages of a public defender's office (e.g., the ability to enforce standards) while still allowing the county to access the resources of a private bar. ${ }^{184}$ The office opened in 2009, and a director, two caseworkers, and an administrative assistant joined the team thereafter. ${ }^{185}$ With additional grant money from TIDC, Lubbock County expanded the program to provide representation in all felony and misdemeanor cases by

171. $I d$.

172. Id.

173. Id.

174. Id.

175. Id.

176. See Partnerships, supra note 132, at 30.

177. Id.

178. Id.

179. Id.

180. Robbins, supra note 170.

181. See id. TIDC awarded the grant to Lubbock County in 2009. Id. From 2009-2013, it disbursed \$662,623 for the program. TIDC Discretionary Grant Payments, supra note 44.

182. Partnerships, supra note 132, at 30.

183. Id.

184. Id.

185. Id. 
$2012 .^{186}$

To qualify for the mental health wheel, the office requires attorneys to attend a minimum of eight hours of training arranged by the LPDO; the Executive Director then assigns attorneys to cases as deemed appropriate. ${ }^{187}$ The program is unique because it offers protection to mentally ill defendants on both the front and back end of representation. ${ }^{188}$ On the front end, it contracts with local mental health organizations to conduct mental health screenings of each inmate booked in jail. ${ }^{189}$ During a face-to-face interview, licensed mental health professionals screen the inmates, which helps prevent defendants from falling through the cracks. ${ }^{190}$ After disposition of the case, caseworkers work to provide defendants with access to treatment and additional support services. ${ }^{191}$ Many clients lack familial support. ${ }^{192}$ The caseworkers stay in touch with clients and encourage them to visit, which "has made a lot of difference in some of their lives." 193

The MAC program averages approximately 743 appointments per month. ${ }^{194}$ It has improved accountability and is a smart and efficient use of county dollars. ${ }^{195}$ Most importantly, it relocates defendants with mental illness to an appropriate facility with the adequate resources to address the issues underlying the defendant's entry into jail. ${ }^{196}$

\section{Mental Health DEFENDER PROGRAMS Funded BY TIDC}

Texas's mental health funds rank among the lowest in the country. ${ }^{197}$ Rapid

186. See Indigent Defense Programs Lubbock, supra note 133. TIDC disbursed an additional $\$ 2,137,261$ to the program from 2012-2015. TIDC Discretionary Grant Payments, supra note 44. It now has a Chief Defender/Executive Director and over seven full time employees including a mental health supervisor. See Tex. Indigent Def. Comm'n, Plan of Operation: Lubbock County Managed Assigned Counsel Program 2-5, available at http:/tidc.tamu.edu/ DGReportDocuments/212-12-D06\%20Plan\%20Of\%20Operation.pdf [https://perma.cc/Z4HTM4X6] [hereinafter Plan of Operation: Lubbock County Managed Assigned Counsel Program].

187. See Plan of Operation: Lubbock County Managed Assigned Counsel Program, supra note 186 , at 3,6 .

188. See generally Partnerships, supra note 132.

189. Id. at 31 .

190. Id.

191. Id.

192. Id.

193. Id.

194. Indigent Defense Programs Lubbock, supra note 133 (see Appendix table).

195. See id.; Partnerships, supra note 132, at 31.

196. See Robbins, supra note 170.

197. Julie Butterfield, Mental Health Care Funding Dodges Cuts in Texas' 85th Legislative Session, Nat'L All. ON Mental Illness Greater Hous. (Nov. 9, 2016), https://namigreaterhouston.org/mental-health-care-funding-dodges-cuts-texas-85th-legislativesession/ [https://perma.cc/6UUU-MY8B]. 
population growth coupled with historic underfunding of mental health burdens criminal justice facilities. ${ }^{198}$ "Jails hold more individuals with mental health illnesses and/or substance abuse disorders than any other public institution."199 TIDC ultimately made funding mental health programs a priority. Through its discretionary grant programs, TIDC has encouraged jurisdictions across the state to develop mental health initiatives. Although each program operates differently, collectively they focus on creating systemic solutions to treat mentally ill defendants with an eye towards successful reintegration into the community. Since 2003, TIDC has disbursed approximately $\$ 6.4$ million through its discretionary grant programs for mental health initiatives, including the first freestanding mental health public defender office in the country. ${ }^{200}$

\section{A. Travis County Mental Health Public Defender Office (MHPD)}

In November 2006, TIDC awarded Travis County a $\$ 500,000$ grant to establish its own freestanding MHPD. ${ }^{201}$ The program has paid for itself in cost avoidance, and there is a direct cost-benefit to the taxpayers now shouldering the bill. ${ }^{202}$ The program's mission is to provide "specialized criminal defense and intensive social services support to indigent defendants who are experiencing significant mental illness. $" 203$

The office opened its doors with one full time attorney, an attorney/program director, two social workers, a case management coordinator, and two case workers dedicated to serving mentally ill clients charged with misdemeanors. ${ }^{204}$ It conditions entry upon the diagnosis of at least one of the following: schizophrenia, bipolar disorder, major depression, or schizoaffective disorder. ${ }^{205}$ But it is cognizant of the complexity of mental health and remains flexible to

198. Id.

199. Smart Justice, Meadows Mental Health Policy Inst., http://texasstateofmind.org/ focus/smart-justice/ [https://perma.cc/BRU6-SVQM] (last visited Nov. 24, 2017).

200. LAR Report 18/19, supra note 28, at 4.A., p. 4, 4.B., p. 1; Travis Cty. Justice Planning, Travis County Mental Health Public Defender Office 5 (2016), available at https://www.traviscountytx.gov/images/criminal_justice/Doc/mhpd_evaluationfeb-2016.pdf [https://perma.cc/92AR-RZBY] [hereinafter TRAvis CTY. Justice PlanNing].

201. Travis Cty. Justice Planning, supra note 200, at 5. TIDC also awarded Travis County a grant for a managed assigned counsel program in 2015. TIDC Discretionary Grant Payments, supra note 44. From 2007 to 2011, TIDC has disbursed approximately \$1,284,523 to Travis County for the two programs. Id. The county matched the state funding and is now solely county-funded. Liz Carmack, Spending Sanely, CounTy MAG., Nov.-Dec. 2012, at 39, available at http://www.tidc.texas.gov/media/36975/121212_Travis_CountyMag.pdf [https://perma.cc/AH8BY8BS].

202. See Carmack, supra note 201, at 40.

203. See Travis Cty. Justice Planning, supra note 200, at 3.

204. Id. at 5 .

205. Id. at 3 . 
defendants who do not fit neatly into a specific category. ${ }^{206}$

The office assigns qualified participants to either a MHPD attorney or a private attorney on a mental health "wheel" depending on the severity of the participant's symptoms. ${ }^{207}$ Clients that present severe mental illness symptoms are assigned to MHPD attorneys, while private attorneys from the mental health wheel represent defendants with less severe symptoms. ${ }^{208}$

Key to Travis County's success is its emphasis on case management and holistic representation. ${ }^{209}$ The office places equal attention and resources on both legal representation and social services. ${ }^{210}$ In fact, MHPD case workers, attorneys, and social workers are strategically located within the same suite of offices to facilitate collaboration. ${ }^{211}$ Every client assigned to a MHPD attorney is also assigned to a case worker or social worker from the office. ${ }^{212}$ MHPD social workers and caseworkers are essential to the efficacy of the program. ${ }^{213}$ They meet with the clients to identify the underlying problems that contributed to their entry into the criminal justice system and help clients formulate goals they wish to accomplish in the program. ${ }^{214}$ Through intensive case management, as well as support in the community, the MHPD "team" helps the client attain these goals. ${ }^{215}$ Like many other mental health programs, the social worker assists participants with "housing, benefits, [and] medication compliance." 16 But intensive case management goes a step further. ${ }^{217}$ Social workers provide clients with constant support and are active participants in their client's reintegration into society - they attend psychiatric/medical appointments with the client, work with the Social Security Administration to help reinstate the client's benefits, and provide support well past legal disposition of the case. ${ }^{218}$

By providing tailored legal and social assistance to mental health defendants, Travis County MHPD has helped produce better outcomes for its mentally ill clients and has saved taxpayers money. ${ }^{219}$ In a Recidivism Outcome Analysis of five years (FY 2009-2013) conducted by Travis County Justice Planning, Travis County MHPD clients had lower recidivism rates than those from the mental

206. Id.

207. Id. Attorneys appointed from this mental health wheel "have additional training in mental health and the [difficult] issues it can present in criminal cases." Id. at $3 \mathrm{n}$.1. There is an attorney list for misdemeanors and a separate one for felonies. Id. at 3; Carmack, supra note 201, at 39.

208. Travis Cty. Justice Planning, supra note 200, at 3.

209. See id. at 6; Carmack, supra note 201, at 40.

210. Travis Cty. Justice Planning, supra note 200, at 6; Carmack, supra note 201, at 40.

211. Travis Cty. Justice Planning, supra note 200, at 6.

212. Id.

213. Carmack, supra note 201, at 40.

214. See Travis Cty. Justice Planning, supra note 200, at 6.

215. $I d$.

216. Carmack, supra note 201, at 40.

217. See Travis Cty. Justice Planning, supra note 200, at 6.

218. Id.

219. See Carmack, supra note 201, at 39-40. 
health wheel. ${ }^{220}$ The office's clients also had fewer total jail bed days for new bookings than the assigned counsel clients. ${ }^{221}$ Investing in mental health has proven beneficial not only to taxpayers and mentally ill defendants, but also to the criminal justice community — other defenders and justice service professionals go the Travis County MHPD office for training, referrals, and advice. ${ }^{222}$ That is good government.

\section{B. The Mental Health Division of the Harris County Public Defender's Office}

Harris County is the largest county in Texas, and its criminal justice policies have historically impacted the state's criminal justice system disproportionately. ${ }^{223}$ In 2012 , the county had a population of over 4.2 million, making it larger than the population of twenty-four states. ${ }^{224}$ Consequently, it houses the third largest jail in the country. ${ }^{225}$

Given the size of its population, the absence of a defender program in Harris County became an obvious concern. ${ }^{226}$ After two years of strategic planning, and with an infusion of a TIDC discretionary grant of approximately $\$ 4.2$ million in 2010, Harris County became one of the then nineteen public defender offices in Texas. ${ }^{227}$

The Harris County Public Defender (HCPD) has four legal divisions including mental health, appellate, juvenile, and trial. ${ }^{228}$ The Mental Health Division (MHD) has four public defenders, three master's level psychosocial workers, and a onetime investigator. ${ }^{229}$ The office provides specialized defense services to defendants with mental illness. ${ }^{230}$ The MHD team has experience in mental health issues and has specialized training in mental health law. ${ }^{231}$ A 2016 report by TIDC stated that MHPD clients were five times more likely to receive

220. See Travis Cty. Justice Planning, supra note 200, at 4.

221. Id.

222. Carmack, supra note 201, at 40.

223. Tony Fabelo et al., Improving Indigent Defense: Evaluation of the Harris County Public Defender, 11 (2013), available at http:/tidc.texas.gov/media/23579/ jchcpdfinalreport.pdf [https://perma.cc/S6XU-C2CW].

224. Id.

225. Meagan Flynn, What You Can Expect to See Under Kim Ogg as Harris County District Attorney, Hous. Press (Nov. 10, 2016, 7:00 AM), http://www.houstonpress.com/news/what-youcan-expect-to-see-under-kim-ogg-as-harris-county-district-attorney-8935097 [https://perma.cc/HUP4-HJ8C].

226. See id.; FABELO ET AL., supra note 223, at 13.

227. FABELO ET AL., supra note 223, at 9, 11, 13-14.

228. Id. at 15; Tex. Indigent Def. Comm'n, Harris County Public Defender Mental Health Program (unpublished memorandum) (on file with Texas Indigent Defense Commission) [hereinafter Harris County Public Defender Mental Health Memo].

229. FABELO ET AL., supra note 223, at 15.

230. Id.; Harris County Public Defender Mental Health Memo, supra note 228.

231. FABELO ET AL., supra note 223, at 15. 
a dismissal than similarly situated defendants. ${ }^{232}$ Dismissals allow mentally ill defendants to focus on treatment, and the office's social workers help connect defendants with mental health related services. ${ }^{233}$

The office relies mostly on appointments from the "wheel." ${ }^{234}$ Harris is unique in that it uses an algorithm to identify defendants with "a likelihood that mental illness and/or intellectual disability is/are a factor in the defendant's arrest[.]" ${ }^{\prime 235}$ Specifically, for every docket setting, it constructs a special needs sheet on each defendant that lists various identifiers including, but not limited to, the charge, past or current mental health diagnoses, and previous medications. ${ }^{236}$ The algorithm then searches a special needs database to identify the defendants at first appearance. ${ }^{237}$ This approach gives arrestees in a mental health unit or persons prescribed psychotropic medications priority in assignment in HCPD's mental health division. ${ }^{238}$

\section{Bexar County Public Defender's Office: Public Defender Representation at Magistration}

Article 15.17 of Texas's Code of Criminal Procedure mandates that arrestees be taken before a magistrate judge within forty-eight hours of arrest. ${ }^{239}$ The magistrate must determine the arrestee's indigency, inform the arrestee of the charges against him, explain to him his constitutional rights, and set bail. ${ }^{240}$ For arrestees believed to have a mental illness, Texas statute allows magistrates to release those who qualify on a personal bond, usually requiring treatment as a condition of release. ${ }^{241}$

Arrestees generally appear at these initial hearings without legal representation. ${ }^{242}$ But even if the magistrate determines that the arrestee qualifies for a court-appointed attorney and a personal bond, the process takes several

232. Id. at 2 .

233. See generally id.

234. Id. at 12 .

235. Harris Cty. (Tex.) Crim. CT. AT LAW Loc. R. 24.5.4.1.1 (2017), available at http://www.ccl.hctx.net/attorneys/rules/rules.pdf [https://perma.cc/PVG9-74ML].

236. FABELO ET AL., supra note 223, at 15 n. 48, 27.

237. Id.

238. $I d$.

239. Tex. Code Crim. Proc. AnN. art. 15.17 (West 2015).

240. Id.

241. Tex. Code Crim. Proc. Ann. art. 17.032 (West 2011). To be eligible, arrestees cannot have a charge or conviction for certain violent offenses. See id. They must also be examined by a mental health expert. Id. And the magistrate must determine that appropriate mental health services are available. $I d$.

242. Kellie A. Dworaczyk, State grant funds legal aid for some arrestees with mental illness, House RESEARCH ORG. (Dec. 2, 2015), https://txhronews.wordpress.com/2015/12/02/state-grantfunds-legal-aid-for-some-defendants-with-mental-illness/ [https://perma.cc/PK2K-Q2HN]. 
days. ${ }^{243}$ The Bexar County Public Defender Office (“BCPDO”) streamlines this process. ${ }^{244}$ By providing representation to arrestees with mental illness at an Article 15.17 hearing, BCPDO attorneys can facilitate an arrestee's release on a personal bond at the hearing, pursuant to an agreement to seek mental health treatment. ${ }^{245}$ The program is the "first of its kind in Texas"246 and, in less than two years, has had a considerable amount of success. ${ }^{247}$

TIDC awarded Bexar County a $\$ 600,000$ grant in 2015 in hopes of diverting mentally ill defendants at 15.17 hearings from jail to treatment. ${ }^{248}$ The grant enables attorneys from BCPDO to maintain a constant presence at the Central Magistration Facility ("CMAG"), where Article 15.17 hearings are held, so that they can provide defendants with immediate access to counsel and support. ${ }^{249}$ The attorney's early presence facilitates quicker release from jail and immediate access to treatment. ${ }^{250}$ Even short periods of incarceration can harm arrestees with mental illness. ${ }^{251}$ By guaranteeing representation at a 15.17 hearing, arrestees avoid languishing in a jail ill-equipped to handle a person's often complex mental health needs. ${ }^{252}$ In fact, arrestees represented by BCPDO are more likely to complete the requirements of a personal bond, i.e. mental health treatment, than non-BCPDO arrestees. ${ }^{253}$

An arrestee's release on a personal bond is a team effort-BCPDO attorneys collaborate with a mental health assessor and clinician, district attorney, magistrate judge, and detention staff throughout the process. ${ }^{254}$ After determination of indigency, the attorneys advise the arrestees on their rights and discuss the possibility of release on a personal bond with mental health treatment

243. Grant will Provide Public Defender to Indigent Mentally Ill, BeXar Cty. Pub. Def. OfFICE (June 5, 2015), available at https://www.bexar.org/ArchiveCenter/ViewFile/Item/2557 [https://perma.cc/5BKQ-BSMP].

244. Michael L. Young, First Annual Review of Public Defender Representation at Central Magistration 10 (2015/2016), available at http://tidc.tamu.edu/ DGReportDocuments/212-16-D04\%20Bexar\%20MHPD\%20Report\%20FINAL\%2010-19-16.pdf [https://perma.cc/TB8H-DV4L].

245. Id. at 6,10 .

246. Id. at 10 .

247. Id. at 8 .

248. Id. at 6; Dworaczyk, supra note 242. Currently, $\$ 188,674$ of the grant has been distributed. TIDC Discretionary Grant Payments, supra note 44.

249. See Young, supra note 244 , at 1 . The BCPDO staffs CMAG with three assistant public defenders, who operate at the facility twenty-four hours a day, five days a week. Id. at 2.

250. Id. at 1 .

251. See Norman Lefstein, Time to Update the 'ABA Ten Principles' for the 21 st Century, 40 CHAMPIOn 42, 48-50 (2016).

252. See Tamar M. Meekins, "Specialized Justice": The Over-Emergence of Specialty Courts and the Threat of a New Criminal Defense Paradigm, 40 Suffolk U. L. Rev. 1, 25 (2006).

253. See Young, supra note 244, at 1 .

254. Id. at 1-2. 
as a required condition of the bond..$^{255}$ Once a client consents to these requirements, a mental health assessment and personal bond interview are performed. ${ }^{256}$ The BCPDO attorney then works with the district attorney to formulate a recommendation for release on a personal bond. ${ }^{257}$ The mental health assessment, agreed recommendation, and personal bond interview are all submitted to the magistrate who then determines at a "Mental Health Docket" whether to grant or deny the personal bond. ${ }^{258}$ The entire representation from start to finish spans from three to nine hours. ${ }^{259}$ Special Order No. 67606, issued by the Bexar County District Court Judges, authorizes BCPDO attorneys to represent indigent clients with qualifying mental illness only for the limited purpose of magistration if representation is related "solely to the determination of the bond and the conditions of the bond." ${ }^{260}$ If the defendant's charge is a misdemeanor, MHPDO can continue to represent the client thereafter. ${ }^{261}$ Upon release from CMAG, the clients have an intake appointment and can expect to see a psychiatrist in less than two weeks, an incredible improvement from the average waiting time of three to six months. ${ }^{262}$

Since its inception, BCPDO has experienced a $150 \%$ increase in defendants released on personal bonds. ${ }^{263}$ More impressively, the number of clients assessed for diversion in a set time period increased from 1,982 in 2015 to 2,402 in $2016 .{ }^{264}$ The importance of a BCPDO attorney at 15.17 hearings cannot be overstated - clients represented by BCPDO are more likely to be granted personal bonds, resulting in better case dispositions and quicker treatment times. ${ }^{265}$ They are also more likely to engage in mental health services. ${ }^{266}$ Active engagement in mental health services is critical to the efficacy of any program aiming to divert arrestees with mental illness from jail to treatment. ${ }^{267}$

\section{COMAL COUNTy CliEnT CHOICE PROGRAM}

In 2012, TIDC staff collaborated with various criminal law experts including

255. $I d$.

256. Id.

257. Id. Upon gathering information about the arrestee, BCPDO attorneys work with prosecutors to develop a joint recommendation for the arrestee's release. Dworaczyk, supra note 242 .

258. See Young, supra note 244, at 2. "Arrestees released on personal bond must agree to the supervision by the Bexar County Pre-Trial Services Department." Dworaczyk, supra note 242.

259. See Young, supra note 244, at 2.

260. Id.

261. Id. at 9 .

262. Id.

263. Id. at 6 .

264. Id.

265. Id. at 7.

266. Id. at 8 .

267. Id. at 8, 10-11. 
Professor Norman Lefstein, Dean Emeritus and Professor of Law at Indiana University Robert H. McKinney School of Law and Steven Schulhofer of New York University School of Law to plan an unprecedented model in the United States for providing counsel to persons without the financial means to hire counsel. ${ }^{268}$ The decision to pilot test a choice model in Comal County has placed it at the "forefront of innovation" in indigent defense services. ${ }^{269}$ Although new to the United States, the model had been tested outside of the country; empirical evidence from countries such as Scotland and England was encouraging. ${ }^{270}$ The public defender office in Edinburg, Scotland explained that counsel appointed by judges "consistently had lower 'levels of trust and satisfaction' from their clients." "271 It implemented a client choice program to give defendants a voice in the process to enhance the independence of the defense function and allow the defendant, not the judge, to select the counsel to provide legal representation. ${ }^{272}$

The model invited speculation and was not without its critics. ${ }^{273}$ Supporters thought it would incentivize lawyers to do better work-lawyers would have to compete with other lawyers for clients to earn repeat business. ${ }^{274}$ Traditionally in Texas, judges appoint attorneys from an attorney "wheel."275 Attorneys can ultimately feel beholden to judges whose interests may diverge from the defendant's interests. ${ }^{276} \mathrm{~A}$ client choice program realigns an attorney's obligations to the client. ${ }^{277}$ Critics, on the other hand, contend that clients have an inadequate understanding of the necessary skills of an effective lawyer. ${ }^{278}$ Others noted that a client choice system would give an unfair advantage to habitual offenders who have a better understanding of the strengths and weaknesses of available counsel. ${ }^{279}$ Many worried that the most popular lawyers would be overloaded with cases. ${ }^{280}$ These arguments were the part of the backdrop for designing and testing a client choice program in Comal County. ${ }^{281}$

"Client choice did not significantly change court procedures." 282 In fact, the

268. See M. Elaine Nugent-Borakove et al., The Power of Choice, The Implications of a System Where Indigent Defendants Choose Their Own Counsel 1 (2017), available at http://www.jmijustice.org/wp-content/uploads/2017/04/The-Power-of-Choice_29-MAR-2017.pdf [https://perma.cc/6EQS-P2KY].

269. Id. at 42 .

270. Id. at 3.

271. Id.

272. See id. at 37-38.

273. Id. at 4-6.

274. Id. at 4.

275. Id. at 17 .

276. Id. at 4.

277. See id. at 5.

278. Id.

279. Id.

280. See id. at 4-5.

281. Id. at 4-6.

282. Id. at 17. 
process of introducing the option to defendants was largely invisible to judges and attorneys. ${ }^{283}$ Likewise, eligibility for appointed counsel remained the same. ${ }^{284}$ The Magistrate's Warning Form was slightly altered to give the defendant a choice about the manner in which a lawyer would be selected. ${ }^{285}$ The document made clear that if defendants were found indigent, they had a choice to select their own lawyer (from a list held by the court) or have the court appoint them a lawyer. ${ }^{286}$ Defendants who elected to choose their own lawyer were afforded time to review a binder containing Lawyer Information Forms ("LIF") listing basic information about each eligible lawyer. ${ }^{287}$ While some magistrates complained that the attorney forms lacked sufficient information to make a well-informed decision, several system actors reported that defendants' decisions were often influenced by the advice of family members or through word of mouth (although, in larger jurisdictions, it may be more difficult for clients to learn of attorneys' reputations for quality defense). ${ }^{288}$

Some lawyers voiced concern at the level of uncertainty client choice introduced into the structure of indigent defense. ${ }^{289}$ Under this new system, lawyers cannot depend solely on court appointments for income. ${ }^{290}$ But this increased uncertainty generally has not inhibited attorneys from participating. ${ }^{291}$ Defenders were asked both before and after implementation of the client choice program their reasons for accepting indigent defense. ${ }^{292}$ The answers remained similar: (1) "It's income and giving back to the community"; (2) "I take cases to get experience"; and (3) "I do not take cases for the money. I like helping people, and it's a fun area of law." 293

Although the program is still in its infancy, participating lawyers have expressed satisfaction in their clients' increased level of trust by having a more active role in the process. ${ }^{294}$ Because defendants personally select their attorney, they defer more to the lawyer and trust his or her advice. ${ }^{295}$ Likewise, the program

283. See id.

284. Id. at 15 .

285. Id. at 52 .

286. See id. at 15, 51-52.

287. Id. at 15. The original plan in the blue print was to give defendants forty-eight hours to make their choice. $I d$. at 55. However, Texas requires defendants receive appointed counsel within seventy-two hours of their request. See Tex. Code Crim. Proc. AnN. art. 1.051 (West 2015). The forty-eight hour requirement was ultimately not implemented because of concerns that forty-eight hours would impede this statutory requirement. See NUGENT-BORAKOVE ET AL., supra note 268, at 15,55 .

288. Nugent-Borakove et AL., supra note 268, at 16.

289. Id. at 21 .

290. Id.

291. See id. at 21-22.

292. See id.

293. Id. at 21.

294. Id. at 24 .

295. Id. 
does provide some market-based incentives that are expected to enhance attorneyclient relations and improve overall representation in furtherance of Gideon's promise. ${ }^{296}$

\section{INNOCENCE PROJECTS AT TEXAS LAW SCHOOLS}

The Texas Legislature allocates $\$ 600,000$ per biennium to establish innocence clinics at each of Texas's six public law schools. ${ }^{297}$ TIDC contracts with these law schools to help operate the projects at a cost of $\$ 100,000$ per year per law school. ${ }^{298}$ Participating law schools include: (1) Thurgood Marshall; (2) the University of Houston; (3) the University of Texas; (4) North Texas; (5) Texas A\&M; and (6) Texas Tech University. The innocence programs provide multiple benefits to the State - they provide a forum for students to learn the causes and consequences of wrongful convictions and provides hands-on experience investigating real cases under a supervising attorney. ${ }^{299}$ Simultaneously, they help facilitate release for innocent people, effectuating systemic improvement of Texas's criminal justice system. ${ }^{300}$ Convicting an innocent person has serious consequences not only for the wrongfully convicted person's family, but for society; when a person is wrongfully convicted, the actual perpetrator often continues to commit crimes. ${ }^{301}$ Texas's innocence projects close a gap in the "continuum of protections against wrongful conviction[s]." 302

While TIDC oversees the innocence projects via a contract with each host law school, legislative guidance on its structure is broad and, consequently, substantial differences remain among the funded projects. ${ }^{303}$ Unlike most of its law school counterparts, which are located within the administration of their respective law schools, Texas Tech University and Texas A\&M have meaningfully collaborated and have contracted for its services through an external provider, the Innocence Project of Texas ("IPTX"). ${ }^{304}$ The non-profit primarily answers to its board of directors rather than the university, which gives it a degree of independence not enjoyed by the other law schools. ${ }^{305}$

It uses resource development strategies including fundraising and grant-

296. Id. at 22 .

297. See PrIMER, supra note 9 , at 5.

298. Id.

299. Dottie Carmichael \& Heather Caspers, Tex. A\&M Pub. Policy Research Inst., An Evaluation of the TeXas Innocence Projects 1 (2015), available at http:/tidc.texas.gov/ media/38168/1 An-Evaluation-of-The-Texas-Innocence-Projects.pdf [https://perma.cc/65KM-38V6] [hereinafter TeXAs InNOCENCE PROJECTS].

300. Id.

301. Id.

302. Id.

303. Id. at 2 .

304. Id. at vii. Texas A\&M School of Law also runs its innocence clinic through IPTX.

305. Id. 
writing to obtain additional funding beyond the state-allocated funding. ${ }^{306}$ As a result, IPTX has a more "diverse portfolio of innocence initiatives." ${ }^{" 307}$ Its relatively autonomous operation allows it to focus its entire energy and resources on exonerating wrongfully convicted people, the underlying objective of innocence projects. ${ }^{308}$ Whatever structure a law school chooses, meaningful monitoring and reporting procedures are necessary to facilitate early detection and protection against potential "fraud, waste, and abuse." 309

Despite the law schools' diverging structures, Texas's innocence projects share common eligibility criteria. ${ }^{310}$ Capital death cases and applications for civil damages are excluded as a condition of funding. ${ }^{311}$ All applicants must claim "actual innocence"-failure to meet these requirements results in an automatic rejection. ${ }^{312}$

But other conditions are determined locally. ${ }^{313}$ At IPTX, forensic cases that involve "junk science" are prioritized. ${ }^{314}$ For most clinics, applications for review go through a two-step screening process. ${ }^{315}$ Initially, students review preliminary information, generally in the form of a letter from an inmate requesting help..$^{316}$ To facilitate coordination, each letter is logged into a central online database. ${ }^{317}$ If prima facie evidence exists, IPTX sends a questionnaire requesting additional information, step two. ${ }^{318}$

The vehicle IPTX uses to find cases sets it apart from other innocence projects. Rather than solely relying on inmate letters, IPTX discovers many of its cases through institutional reviews, which target a single source of conviction. ${ }^{319}$ In 2007, IPTX partnered with Dallas County's newly established Conviction Integrity Unit (CIU). ${ }^{320} \mathrm{CIU}$, which later became a national model, was created by Craig Watkins, a defense lawyer turned Dallas County District Attorney, who embarked on a mission to improve criminal justice in a manner that would impact forensic science and its practices statewide. ${ }^{321}$ IPTX's reputation for exonerating the wrongfully convicted caught the attention of the District Attorney. ${ }^{322}$ Dallas

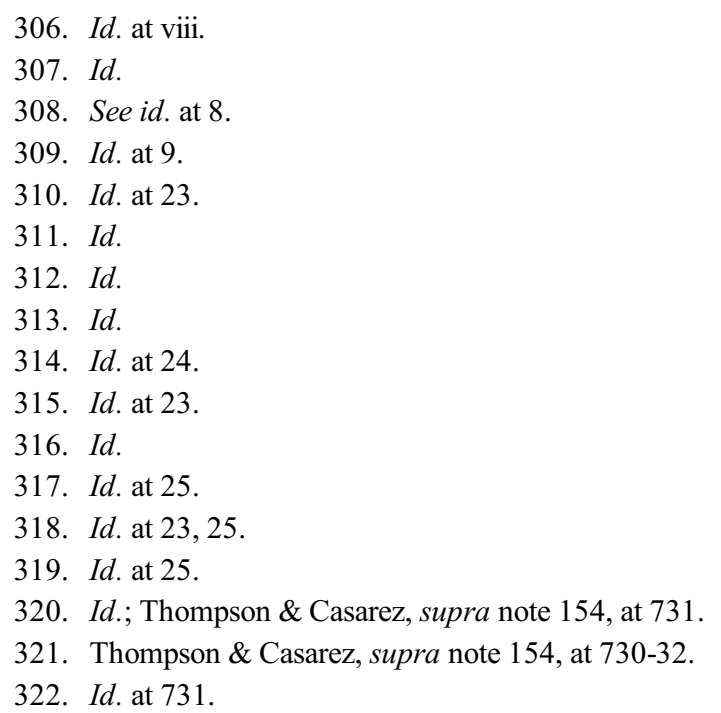


led the country in DNA exonerations at the time. ${ }^{323}$ In an effort to capitalize and promote CIU to the national stage, the unit partnered with IPTX to facilitate the process of reviewing past convictions in search for additional wrongful convictions within the county. ${ }^{324}$ The partnership gave IPTX "an unprecedented degree of access" to case files and the power to subpoena key witnesses. ${ }^{325}$ It also enabled IPTX to undergo large-scale institutional reviews, which has made IPTX a widely known resource for inmates seeking help. ${ }^{326}$

Once cases process through initial intake, they are stamped as "pending investigation" until assigned to a student. ${ }^{327}$ Investigation is where the majority of work takes place. ${ }^{328}$ The process is not only great hands-on training for law students, but it is the means by which clinics find wrongfully convicted individuals a path to exoneration. The number of cases investigated varies among projects. ${ }^{329}$ The acceptance ratio at IPTX is very selective. It strives to focus its limited resources "on cases backed by forensic evidence." "330 Students" participation also affects the speed of investigation-law students enrolled in year-long programs are able to follow cases longer and can "apply [the] advanced skills developed with experience." 331

Upon investigation, the projects must determine if there is a legitimate path to exoneration. ${ }^{332}$ Although many projects have pursued legal remedies, IPTX through Texas Tech and now Texas A\&M has achieved more exonerations than all other projects combined. ${ }^{333}$ PPRI attributes this success to its "resources and relationships." ${ }^{334}$ Most of Texas's innocence projects work within the confines of state funding. IPTX has successfully expanded the reach of its program beyond those confines through grant-writing, fundraising, and developing networks of well-connected partners. ${ }^{335}$ It strives to place Texas's leading post-conviction attorneys to serve on its Board of Directors. ${ }^{336}$ The Board not only provides invaluable expertise, but it also actively refers cases for investigation. ${ }^{337}$

Through its outreach, IPTX has become a valuable resource in Texas's criminal justice reform. TFSC, described as "one of the most important forensic science reform groups in the nation," partnered with agencies including IPTX to

323. Id.

324. Id.

325. Id.

326. Id. at 730-31; TEXAs INNOCENCE ProjeCts, supra note 299, at 30.

327. TeXAs InNOCEnCE Projects, supra note 299, at 30.

328. Id. at 33 .

329. Id.

330. $I d$.

331. Id. at 36 .

332. Id at 37.

333. Id. at 41 .

334. Id.

335. Id. at 41-42.

336. Id. at 42 .

337. Id. 
undergo large-scale systematic reviews of particular areas of forensic science. ${ }^{338}$ TFSC also sought the help of IPTX to review thousands of cases with convictions regarding arson testimony in Texas. ${ }^{339}$ After contacting over one thousand Texas defendants convicted of arson, IPTX found thirty-three arson convictions that required further investigation. ${ }^{340}$ By 2014, IPTX, upon collaboration with the state fire marshal and a panel of legal and forensic experts, had reviewed nine of those cases. ${ }^{341}$ Five of those nine were determined to have been decided on unsound arson techniques. ${ }^{342}$ By 2016, the Court of Criminal Appeals had affirmed a district court's holding that the defendant, in one of those five cases, had "presented overwhelming evidence of actual innocence." ${ }^{\text {"343 }}$ Additionally, TFSC has sought IPTX's help with the country's first ever statewide review of convictions involving hair microscopy testimony. ${ }^{344}$ IPTX, in collaboration with other experts, reviewed eleven of 287 cases, five in which testimony amounted to "notifiable error." 345

Texas's innocence projects are prized by the host law schools. The projects contribute to freeing the wrongfully convicted and help the schools achieve their own strategic objectives related to student learning and social justice. They are an innovative collaboration that utilize the talent of bright law students for "the most important yet intractable problems of our time: the wrongful conviction of innocent people." ${ }^{346}$ To date, Texas's innocence projects have contributed to the exoneration of fifteen convicted Texans. ${ }^{347}$ With the help of state funding and support by TIDC, the programs can continue to help those victim to the blemishes of our criminal justice system. ${ }^{348}$

\section{TEXAS TECH LAW SCHOOL REGIONAL EXTERNSHIP PROGRAM}

Texas Tech Law School offers an unparalleled Regional Externship Program that places third-year law students with nonprofit and governmental organizations and in-house legal departments in Texas's major metropolitan areas including Austin, Dallas, Houston, San Antonio, and Lubbock. Placements include the Texas Supreme Court, Texas Indigent Defense Commission, San Antonio Spurs General Counsel's Office, and legislative placements at the House Parliament's Office, the Office of the Speaker of the House of Representatives, and the Offices

338. Thompson \& Casarez, supra note 154 , at 742.

339. Id. at 743 .

340. Id.

341. Id.

342. Id.

343. Id.

344. Id.

345. Id. at 744 .

346. Texas Innocence Projects, supra note 299, at 77.

347. See PRIMER, supra note 9 , at 5.

348. Id. 
of Texas State Representatives. ${ }^{349}$ The program is one of only a few in Texas that permits law students to extern full-time for a semester in exchange for receiving twelve hours of academic credit. ${ }^{350}$ Although the program requires students to work at least 500 hours throughout the semester, ${ }^{351}$ during the legislative session, students often exceed that requirement. Because the Texas Legislature meets only biennially, the program makes exceptions for second-year law students to apply for placement in the Legislature during session. ${ }^{352}$ In addition to working at the placement, students attend a support course every other week. ${ }^{353}$ Class discussions cover a wide spectrum of topics from ethical issues and time management in the workplace to remedying bias and inequality in the legal system. Various attorneys from around the metropolitan area attend the classes and lead discussions on these important topics. Students also complete thought-provoking assignments throughout the semester such as a thirty-year resume and meet one-on-one with various mentors in the legal profession. By providing real-life, hands-on practical experience, Tech law students are better prepared to enter the workforce and gain important skills that make for an easier transition into the legal community and workforce upon graduation.

\section{EVIDENCE BASED DECISION-MAKING}

The recent shift in Texas's criminal justice system is in part a product of a certain straightforward practicality within Texas culture that has welcomed the idea of addressing root causes with evidence-based approaches. TIDC promotes compliance and encourages improvement of indigent defense systems in counties throughout Texas via hard data, reports, and strategic planning meetings. ${ }^{354}$ Data collection and analysis is key in pushing indigent defense systems toward improvement. ${ }^{355}$ Statistics help identify deficiencies in indigent defense systems and increasingly funders of defense systems expect quantitative data to justify expenditures. ${ }^{356}$ For TIDC, an evidence-based practice helps it (1) facilitate systematic examination of counties' indigent defense services; (2) document local successes; and (3) provide information to local constituencies and state officials

349. Tex. Tech Univ. Sch. of Law, 2015-2016 CATAlog 12-13 (2015-2016), available at https://www.depts.ttu.edu/officialpublications/pdfs/2015-16_law_catalog.pdf [https://perma.cc/5J58-VVVY].

350. Id. at 12 .

351. Id.

352. Tex. Tech Univ. Sch. of Law, Externship Handbook 5 (2014-2015) (on file with the author).

353. TeX. TeCh UnIV. Sch. OF LAW, supra note 349, at 12.

354. See Keller \& Bethke, supra note 4, at 190.

355. Marea Beeman, Justice Mgmt. Inst., Using Data to Sustain and Improve Public Defense Programs 1 (2012), available at http://69.195.124.207/ jmijust1/wp-content/uploads/ $2014 / 04 /$ Sustaining-and-Improving-Public-Defense-With-Data8-29-2012.pdf [https://perma.cc/FA89-SZY8].

356. Id. at 3 . 
on how the requirements of the FDA as well as Gideon are being met. ${ }^{357}$ TIDC continues to collaborate with expert researchers in the field of indigent defense to conduct data driven projects that support long-term policy development. Most importantly, its data collection enables TIDC to run an open and transparent operation, as described below.

\section{A. Weighted Caseload Study}

Few would dispute that excessive caseloads impede an attorney's ability to provide effective assistance of counsel and often result in a "meet and plead"358 system of representation. Yet, the problem permeates indigent defense systems in Texas. In 2013, the Texas Legislature passed a bill centered on the appointment of counsel for indigent defendants. ${ }^{359}$ It instructed TIDC to conduct a study that would generate caseload standard that would allow attorneys "to give each indigent defendant the time and effort necessary to ensure effective representation. ${ }^{״ 60}$ PPRI assisted with the weighted caseload study. It collaborated closely with the State Bar of Texas, the Texas Criminal Defense Lawyers Association, a twenty-seven member Advisory Panel bearing state and national expertise, and two national caseload scholars, Norman Lefstein, and Steve Hanlon, public interest attorney and General Counsel for the National Association of Public Defense. ${ }^{361}$

Although the legal consensus is that caseloads should be limited, objectively measuring the point at which caseload size interferes with the delivery of effective counsel is challenging. ${ }^{362}$ After considering empirical workload studies and professional judgment standards to develop objective caseload guidelines, PPRI utilized The Delphi Method, "a substantially more rigorous means than professional judgment alone to quantify professional opinion about attorney caseload size." ${ }^{\text {363 }}$ The Delphi Method utilizes a decision-making process that integrates and rationalizes the various opinions of knowledgeable experts (Delphi Panel) and converts them into objective data. ${ }^{364}$ National indigent defense scholars endorse the Delphi Method because it removes elements of bias that can

357. Tex. Indigent Def. Comm'n, Upholding the Constitution: 2008 Annual Report 13 (2008), available at http://www.tidc.texas.gov/media/18591/fy08annualreport.pdf [https://perma.cc/HQJ2-5BA8]; see generally TeX. InDIGENT Def. COMM'N, A STRATEGIC PlAN For IMPROVIng INDIGENT DEFENSE SyStems 1-6 (2010-2015) (on file with Texas Indigent Defense Commission).

358. Dottie Carmichael et al., Tex A\&M Pub. Policy Research Inst., Guidelines for INDIGENT DEFENSE CASElOADS 5 (2015), available at http://www.tidc.texas. gov/media/31818/150122_weightedcl_final.pdf [https://perma.cc/8JF6-72HB].

359. Id at 1 .

360. Id. at xiii.

361. See generally id. at 1-37.

362. Id. at 5 .

363. Id. at 7 .

364. Id. at 7-8. 
impede the validity of group decision-making. ${ }^{365}$

The Texas Delphi Panel consisted of eighteen criminal defense experts selected as representatives of each of Texas's nine Administrative Judicial Regions. ${ }^{366}$ Because of their extensive experience in criminal law, the panelists could holistically conceive of the overall impact of case time on "complex and overlapping case attributes such as charge enhancements, sentencing practices, and client characteristics like detention status, immigrant status, and mental illness." ${ }^{367}$ Unlike previous workload studies, the Texas Delphi Panel made recommendations for cases disposed by trial and by pleas. ${ }^{368}$

The study provides new and important sources of information to guide Texas policymakers. Specifically, data describing how attorneys spend their time on court-appointed cases is now available. As an initial matter, panel members concluded that trials require around " 3.5 times as much time as non-trials at each offense level." ${ }^{369}$ They recommended that high-level felonies require thirty hours to defend. ${ }^{370}$ In regards to case limits per year, the panelists recommended that the maximum number of clients a single attorney should represent in a year is 128 for felony cases and 226 for misdemeanor cases. ${ }^{371}$ These numbers varied only slightly from the recommendations of "surveyed attorneys," affirming their general validity. ${ }^{372}$ During the 2015 survey, the "current practice" numbers exceeded the panelists' recommendations substantially. ${ }^{373}$ The report confirmed that, to ensure effective representation, further reductions were needed. ${ }^{374}$

Defense attorneys "should not accept workloads that, by reason of their excessive size, interfere with the rendering of quality representation or lead to the breach of professional obligations." ${ }^{\text {735 }}$ Caseload guidelines give policy makers and practitioners the necessary tools to define a point when caseloads become excessive. Likewise, the study gives attorneys a tool to self-assess their own performance. Most importantly, adherence to caseload guidelines may prevent jurisdictions from future litigation. Although caseload guidelines don't guarantee effective assistance of counsel, jurisdictions following such guidelines are less likely to be targets of complaint ${ }^{376}$ Regardless, they are an essential component in securing a defendant's Sixth Amendment right to counsel.

365. Id. at 22 .

366. Id.

367. Id.

368. Id. at 24-25.

369. Id. at 25 .

370. Id. at 28 .

371. Id. at 29-30.

372. Id. at 31 .

373. Id.

374. Id.

375. Id at 35 .

376. Id. 


\section{OPEN AND TRANSPARENT GOVERNMENT}

TIDC's success is due in large part to its transparency, flexibility, and accountability. As explained in its FY11 Annual and Expenditure Report, TIDC "strives to make monitoring reviews constructive, [but] not punitive." ${ }^{377}$ It requires each county to submit its annual indigent defense expenditures and indigent defense plans electronically. ${ }^{378}$ Despite initial resistance, all counties are now compliant. ${ }^{379}$

As required by state law, TIDC's Annual Indigent Defense Expenditure Report, available on TIDC's website, provides a snapshot of county expenditures and appointment rates. Counties can submit, update, and compare plans to facilitate problem solving and expand innovation. ${ }^{380}$ Each county's indigent defense plan is also available online to the public. TIDC uses an objective risk assessment tool to determine where an onsite review is warranted. ${ }^{381}$ TIDC conducts an annual desk review of all of Texas's 254 counties. ${ }^{382}$ Onsite review is more comprehensive, but occurs less frequently because of limited resources. Where problems are identified, counties are required to submit formal responses and provide an action plan on how they intend to remedy the problem.

TIDC gives support where needed. It also respects local control - the counties ultimately develop and direct their own indigent defense plans. ${ }^{383}$ But, with autonomy comes responsibility. Through its website, TIDC places the knowledge directly in the hands of those charged with providing indigent defense. This results in a more cost-effective system. More importantly, it reinforces TIDC's commitment to transparency. All tasks undertaken by the TIDC are available on TIDC's website.

\section{TEXAS's CRIMINAL JUSTICE LANDSCAPE}

Although once a strictly "law and order" state focused on incarceration and harsh punishment, Texas has taken meaningful steps to reform its criminal justice system. ${ }^{384}$ The creation of the FDA, and ultimately TIDC, represents Texas's commitment to continual improvement of the indigent defense landscape. By focusing spending on more effective and evidence-based strategies, counties throughout Texas have been able to implement cutting-edge defense systems for its indigent citizens while also saving its taxpayers money. ${ }^{385}$

377. TeX. Indigent Def. Comm'N, supra note 107, at 14.

378. TeX. CRiminal Justice CoAL., supra note 10, at 11.

379. Counties' plans include timing of appointment, attorney fee schedules, methods of attorney selection, and indigency standards. See Bethke, supra note 5, at 240.

380. See Keller \& Bethke, supra note 4, at 190.

381. Tex. CRiminal Justice CoAL., supra note 10, at 11.

382. Id.

383. Id at 6 .

384. Thompson \& Casarez, supra note 154 , at 712.

385. Id. at 713 . 